NBER WORKING PAPER SERIES

\title{
LABOR MARKET SHOCKS AND RETIREMENT: DO GOVERNMENT PROGRAMS MATTER?
}

\author{
Courtney C. Coile \\ Phillip B. Levine \\ Working Paper 12559 \\ http://www.nber.org/papers/w12559
NATIONAL BUREAU OF ECONOMIC RESEARCH
1050 Massachusetts Avenue
Cambridge, MA 02138
October 2006

Acknowledgements: The authors thank Monica Butler, Olivia Mitchell, and seminar participants at the NBER Trans-Atlantic Public Economics Seminar and the NBER Summer Institute Aging Workshop for helpful comments. They acknowledge financial support from Wellesley College. The views expressed herein are those of the author(s) and do not necessarily reflect the views of the National Bureau of Economic Research.

(C) 2006 by Courtney C. Coile and Phillip B. Levine. All rights reserved. Short sections of text, not to exceed two paragraphs, may be quoted without explicit permission provided that full credit, including (c) notice, is given to the source. 
Labor Market Shocks and Retirement: Do Government Programs Matter?

Courtney C. Coile and Phillip B. Levine

NBER Working Paper No. 12559

October 2006

JEL No. H55,J26,J64,J65

\begin{abstract}
$\underline{\text { ABSTRACT }}$
This paper examines how unemployment affects retirement and whether the Unemployment Insurance (UI) system and Social Security (SS) system affect how older workers respond to labor market shocks. To do so, we use pooled cross-sectional data from the March Current Population Survey (CPS) as well as March CPS files matched between one year and the next and longitudinal data from the Health and Retirement Survey (HRS). We find that downturns in the labor market increase retirement transitions. The magnitude of this effect is comparable to that associated with moderate changes in financial incentives to retire and to the threat of a health shock to which older workers are exposed. Interestingly, retirements only increase in response to an economic downturn once workers become SS-eligible, suggesting that retirement benefits may help alleviate the income loss associated with a weak labor market. We also estimate the impact of UI generosity on retirement and find little consistent evidence of an effect. This suggests that in some ways SS may serve as a more effective form of unemployment insurance for older workers than UI.
\end{abstract}

Courtney C. Coile

Department of Economics

Wellesley College

106 Central Street

Wellesley, MA 02481

and NBER

ccoile@wellesley.edu

Phillip B. Levine

Department of Economics

Wellesley College

Wellesley, MA 02481

and NBER

plevine@wellesley.edu 


\section{INTRODUCTION}

Job loss is an empirically important phenomenon for older workers. Between 2001 and 2003, more than 10 percent of workers aged 55-64 experienced job loss (Farber, 2005). Moreover, job loss has significant long-term effects on employment and wages for older workers. Chan and Stevens (1999) estimate that the employment rate of displaced older workers two years after a job loss is 25 percentage points lower than that of similar non-displaced workers and that the median reemployed worker earns 20 percent less than at his previous job.

Given that older workers face a considerable risk of job loss and difficulty finding an equivalent job afterwards, labor market conditions may affect workers' retirement decisions. ${ }^{1}$ This link has largely been overlooked in the extensive previous literature on retirement, which focuses primarily on the role of poor health and financial incentives. Just as health status can act as an important constraint limiting continued work at older ages, so too may labor market conditions be a critical constraint for older workers. If older workers lose their jobs, they may have difficulty finding suitable employment and decide to retire, particularly during periods of economic downturn. ${ }^{2}$

Not only is the link between labor market conditions and retirement relevant for understanding retirement behavior, it is also important because of the interactions with public sector programs. Just as a health shock may bring about unanticipated retirement and income

\footnotetext{
${ }^{1}$ Although we are presuming that retirements may increase (similar to a "discouraged worker effect" - DWE), it is also possible that retirements may decrease. This could happen if the threat of job loss for one individual leads his or her spouse to remain in the labor market beyond the point when they may choose to retire. This is similar to the notion of "added worker effect" (AWE). Empirical evidence for the AWE is mixed; see, for example, Lundberg (1985) and Speltzer (1997). Our estimates can be thought of as measuring the net effect of unemployment on retirement, incorporating both the DWE and AWE.

${ }^{2}$ Workers may also choose to retire in the face of an economic downturn if their wages are cut even if they do not lose their jobs. This possibility seems unlikely, however, given past research on the cyclicality of real wages. Given the nature of the estimated responsiveness of wages to the business cycle among workers who stay on their job (Devereaux, 2001), the retirement elasticity with respect to the wage would have to be enormous to generate a significant retirement response.
} 
insecurity that can be alleviated by government programs, unemployment associated with an economic downturn may have similar implications. The Unemployment Insurance (UI) system is designed to help protect workers, including older ones, from the income loss associated with unemployment. For older workers, UI may provide the resources necessary to weather the storm, offering a bridge towards retirement. At the very least, it may allow workers to delay the take-up of retirement benefits for the period that UI benefits are available. It may also enable them to stay in the labor market long enough to find new work, which may more substantially delay retirement and benefit claiming.

Social Security (SS) offers another form of income that can help overcome earnings loss. While SS is traditionally thought of as a source of support for retired and disabled workers, it may serve as an additional source of support for older workers who lose their jobs. If an older unemployed worker is struggling financially, he may be forced to start collecting SS benefits to make ends meet. Although one does not necessarily need to retire to collect these benefits, benefit receipt is typically linked to retirement (Coile, et al. 2002). In terms of providing income support to older unemployed workers, SS may be thought of as an alternative form of unemployment insurance. ${ }^{3}$

In this paper, we explore the role of labor market conditions in retirement transitions and the extent to which the UI and SS programs affect workers' response to labor market shocks. Specifically, we will address the following questions: (1) Are retirement transitions cyclically sensitive? (2) Do more generous UI benefits reduce the likelihood of retirement transitions? (3) Do SS provisions interact with labor market conditions in affecting retirement transitions? In our analysis, we use pooled cross-sections of data from the March Current Population Survey (CPS)

\footnotetext{
${ }^{3}$ Indeed, Hutchens (1999) suggests that employers may view it as such when making layoffs or offering early retirement windows. Under the implicit contract model he develops, there will be an inefficiently high level of early retirement due to the lack of experience rating in Social Security.
} 
data for over twenty years, as well as March CPS files matched between one year and the next and longitudinal data from the Health and Retirement Survey (HRS).

We have several principal findings. First, we find that the unemployment rate has a positive and significant effect on retirement transitions: an increase in the unemployment rate of 3 percentage points, which corresponds roughly from moving from the peak of an expansion to the trough of a recession, raises the retirement hazard for workers aged 55-69 by 5 to 10 percent. The magnitude of this effect is comparable to that associated with moderate changes in financial incentives to retire and to the threat of a health shock to which older workers are exposed. Second, this effect is evident only when workers hit age 62, suggesting that access to SS benefits may lead unemployed older workers to retire in order to gain that source of income. Third, we find little consistent evidence indicating that more generous UI benefits alter retirement transitions, suggesting that the UI system plays only a minor role at best in assisting older workers who lose their jobs to delay retirement. Taken together, these findings suggest that the SS system may play a bigger role in helping older workers cope with job loss than the UI system.

\section{BACKGROUND AND LITERATURE REVIEW}

\section{A. Institutional Features of UI and SS}

We begin with a brief discussion of the institutional features of UI and SS that are most pertinent for our analysis. The UI system is administered at the state level with federal oversight. As such, there is a good deal of variation in specific provisions across states, although the basic framework of the program is the same. That framework includes two types of eligibility requirements. Workers satisfy "non-monetary eligibility" if they lose a job through no fault of their own and demonstrate that they are actively looking for work. Workers meet "monetary 
eligibility" requirements if they had a sufficient work history prior to job loss. In terms of benefits, individuals typically receive an amount equal to half of their pre-unemployment weekly wage, subject to a minimum and maximum benefit. Since the minimum benefit is typically very low, the major source of state variability in the generosity of UI benefits is the maximum weekly benefit. Some states are considerably more generous than others, both in benefit levels and ease of meeting monetary eligibility requirements. ${ }^{4}$ On average, UI benefits replace approximately 35 percent of lost earnings (U.S. Department of Labor, 2006). Weekly benefits are available for a limited duration, typically 26 weeks. During a recession, however, this maximum benefit duration is often extended to a longer time period.

SS benefits are available to covered workers (those with at least ten years of work experience) starting at age 62. SS benefits are calculated by applying a progressive benefit formula to the worker's average indexed earnings over his best 35 years. The basic monthly benefit amount is then adjusted depending on the age of benefit claim; the adjustment factor is set to be roughly actuarially fair, so that the present discounted value of the stream of benefits received over the worker's lifetime for an average worker will be approximately the same regardless of the age at which he or she claims. A typical newly retired worker receives a benefit of about $\$ 1,000$ per month, which equates to a 42 percent replacement rate relative to career average earnings (Social Security Administration, 2005a and 2005b). Finally, since 1980, covered workers have not been allowed to claim UI and SS benefits simultaneously, although they may claim these benefits sequentially (Hutchens and Jacobson, 2002).

\footnotetext{
${ }^{4}$ In 2004, maximum weekly benefits ranged from $\$ 210$ in Alabama and Mississippi to $\$ 508$ in Massachusetts. Minimum earnings requirements to be eligible for UI ranged from $\$ 130$ in the past year in Hawaii to $\$ 3,520$ in Ohio in that year. See Levine (forthcoming) for a complete list of maximum weekly benefit amounts and annual earnings requirements by state for 2004. For all years, data on benefit levels and eligibility rules are obtained from: Highlights of State Unemployment Compensation Laws (various issues), Comparison of State Unemployment Insurance Laws, (various issues), and Significant Provisions of State Unemployment Insurance Laws (various issues).
} 


\section{B. Previous Literature}

Although little past research has examined the role that unemployment and UI play in retirement decisions in the U.S., related research on the impact of job loss among older workers and the role of unemployment and UI in retirement transitions in other countries does inform our discussion. ${ }^{5}$ The broader literatures that address the determinants of retirement and the role of UI in labor markets are also relevant. We briefly review these past lines of research here.

As discussed in the introduction, work by Farber (2005) and Chan and Stevens (1999, 2001) has established that job loss among older workers is reasonably common and has longlasting negative effects on the future employment prospects and earnings of these workers. Chan and Stevens (2004) look at the effect of job loss on retirement - specifically, they explore whether the lower wages and lost opportunity to accrue additional pension benefits than often follow job loss affect the retirement decision. They find that these are not major contributors to retirement, leading them to conclude that "other barriers to reemployment may be more important explanations for the low employment rates of recently displaced older workers." Our work addresses a related but distinct question, in that we look at whether retirement is cyclically sensitive rather than the effect of job loss on individual workers. Moreover, if "other barriers" such as difficulty in finding new employment at older ages explain why older job losers are so much less likely to be employed than other older workers, then UI may play a key role in helping workers to overcome these barriers. This is the second focus of our study.

\footnotetext{
${ }^{5}$ Rebick (1994) uses time-series evidence for the U.S., Sweden, and Japan to look at the effect of unemployment on the labor force participation rate and rate of Social Security benefit receipt for older workers. This study is subject to the usual critique that it may be difficult to separate causal effects from spurious correlations between trending variables, particularly given the significant changes in U.S. labor force participation since 1950. Hamermesh (1980) makes an early contribution to the literature by examining the effect of UI receipt and UI income on retirement for a sample of workers from the Retirement History Survey. This differs considerably from our empirical strategy, described in more detail below, of using state-level UI policies to identify the effects of UI on retirement.
} 
Despite the lack of research on this in the U.S., analysts from other developed nations have explored these issues. Hallberg (2006) finds that the probability that a worker takes early retirement in Sweden is affected by deviations in aggregate employment in his industry from the long-run trend. Other researchers have shown that many workers' pathway to retirement includes a period of time spent on UI prior to claiming Social Security benefits. This is the case for 7 percent of older workers in Sweden (Palme and Svensson, 2004), 15 percent in Belgium (Dellis et. al., 2004), over 20 percent in France and Germany (Mathieu and Blanchet, 2004; Borsch-Supan et. al., 2004), and nearly 40 percent in Japan (Oshio and Oishi, 2004).

Although little past work has examined the role of UI in retirement transitions, significant bodies of work have examined retirement and UI separately. ${ }^{6}$ One large branch of the retirement literature has focused on the role of financial incentives from Social Security and private pensions, programs which may lead workers to retire earlier if they raise lifetime wealth or later if they are structured such that lifetime benefits rise with continued work (Stock and Wise, 1990; Coile and Gruber, forthcoming). Another major branch of the literature has highlighted the important role of health status (Baker et. al., 2004; Dwyer and Mitchell, 1999) and access to health insurance (Blau and Gilleskie, 2001; Gruber and Madrian, 1995). All these factors have been found to be important determinants of retirement transitions.

Other research has focused on the role that the UI system plays in determining labor market outcomes more generally. Perhaps the most researched question is the relationship between the generosity of the UI system and the duration of unemployment spells. Economic theory predicts that if individuals receive UI payments while unemployed, then they have less

\footnotetext{
${ }^{6}$ Hutchens and Jacobson (2002) present a contribution to a related question. They examine the age patterns of UI receipt before and after the law change that prevented workers from collecting both UI and SS at the same time. They find that prior to the law change, there were substantial spikes in rates of UI receipt exactly at ages 62 and 65 , suggesting that claims for UI were filed along with initial filings for SS. These spikes dissipated in the years following the law change.
} 
incentive to find another job and may remain unemployed longer. Indeed, this may be optimal if it leads to better job matches (c.f. Mortensen, 1986). Empirical evidence supports this prediction, finding that a 10 percent increase in UI benefits leads to a 5 percent increase in unemployment spell lengths (Krueger and Meyer, 2002). Although this work has not focused on older workers specifically, they too may respond by remaining unemployed longer. Further, for older workers additional job search may also mean prolonging labor force participation before retiring and starting receipt of retirement benefits. Past research has not examined this issue. A sizable literature examining the determinants of UI take-up rates exists as well (Anderson and Meyer, 1997), but this literature similarly does not distinguish between the behavior of younger and older workers.

\section{DATA AND EMPIRICAL STRATEGY}

We use several data sources for this project. The use of multiple sources is advantageous because each source provides alternative ways to measure retirement, ${ }^{7}$ the exact definition of which is somewhat ambiguous, and offers different strengths and weaknesses. ${ }^{8}$ If we obtain consistent findings across data sources, we will be able to draw stronger conclusions regarding the relationship between unemployment, government programs, and retirement.

\footnotetext{
${ }^{7}$ In our analysis, we follow the previous literature and treat retirement as an absorbing state, ignoring the possibility of labor force re-entry. The March CPS does not allow us to identify re-entrants due to the short period over which we observe labor force behavior. In the matched March CPS, however, we are able to exclude labor force exits that are followed by rapid re-entry. Only the HRS follows individuals for long enough to allow us to identify long-term labor force re-entry. A full analysis of labor force re-entry is beyond the scope of this project, but analyzing the effect of unemployment and UI on re-entry and the use of bridge jobs may be a fruitful area for future research.

${ }^{8}$ Several differences emerge from our detailed discussion of these data sources below. Our matched March CPS sample is smaller than that from the regular March CPS, but the matched CPS allows us to restrict the sample to individuals with greater labor force attachment and provides us with more time to observe transitions from work to unemployment and/or UI receipt to eventual retirement. While the HRS offers us an opportunity to follow people for an even longer period of time, unfortunately unemployment spells are very difficult to measure in the HRS, UI receipt is captured only every other year, and sample sizes are smaller than in either CPS sample.
} 


\section{A. March Current Population Survey (CPS)}

The CPS is the leading survey of labor market activity in the United States. The monthly survey asks a sequence of questions about the respondent's involvement in the labor market around the time of survey and also collects demographic data. Importantly, state of residence is available, which we use to merge in state-level data on unemployment rates and UI benefits. In March of each year, the "Annual Demographic File" is administered as a supplement to the CPS. Respondents are asked about their income in the preceding calendar year from multiple sources, including UI, SS, and private pensions. ${ }^{9}$ Research has shown that UI receipt measured in this way captures 75 to 80 percent of actual UI receipt (Hotz and Sholz, 2002).

Another important attribute of the Annual Demographic File is that it obtains information on the labor market activity of respondents in the preceding calendar year, including weeks worked, usual hours worked per week, and weeks spent looking for work. Combining this retrospective information along with that obtained in the regular monthly survey, we define a retirement to occur when an older worker reports being in the labor force in the preceding year, but is out of the labor force on the March survey date. We record workers as experiencing some unemployment if they reported looking for work in the past calendar year. ${ }^{10}$

As in Coile and Levine (2006), we focus on workers between the ages of 55 and 69, who are more likely to retire in any given year. Despite the relatively small slice of the population that this group represents, the total sample sizes in the March CPS - 130,000 to 215,000 people

\footnotetext{
${ }^{9}$ The Social Security income variable in the CPS includes Social Security Disability Insurance (SSDI) benefits; there is a separate question about disability income, which refers to private disability insurance income only.

${ }^{10}$ Our definition perhaps provides a slight understatement of unemployment and UI receipt since those activities may have taken place in January or February of year $t$.
} 
per year, depending on the year - are large enough to provide us with a sample of many thousands of older workers when we pool data from the 1980 through 2004 surveys.

\section{B. Matched March CPS Data}

As just described, the March CPS provides a method of constructing what amounts to a two period panel for each respondent. But the structure of the CPS actually enables one to compile a three period panel. Each respondent is surveyed for four consecutive months, then out for eight months, then back in the sample for four months. Thus any CPS respondents interviewed in a March as one of their initial surveys are also interviewed in the following March. ${ }^{11}$ In their second interview, individuals provide contemporaneous information regarding their activity in the survey week, period $t$, and retrospective information for the preceding calendar year, period $\mathrm{t}-1$. When the same individuals were interviewed one year earlier, they provided contemporaneous information for the survey week, period $t-1$, and retrospective information for the preceding calendar year, period $\mathrm{t}-2$. Combining this, we have information on labor market activity in three consecutive years. We define a retirement transition to have occurred when the individual reports working for 13 or more weeks in period $\mathrm{t}-2$, working for less than 13 weeks in period $t$, and being out of the labor force at time t. Assuming that weeks worked are consecutive starting at the beginning of the calendar year, this amounts to saying that individuals are working in March of $\mathrm{t}-2$, not working at March of $\mathrm{t}-1$, and out of the labor force at March of t. Our definition thus requires respondents to have not worked for at least 12 consecutive months to be counted as retired.

\footnotetext{
${ }^{11}$ Because of structural changes in the survey, matches between the 1984 and 1985 surveys as well as the 1994 and 1995 surveys cannot be conducted. For simplicity, all charts will provide values for 1985 and 1995 that are the averages of the surrounding years. These data will not be used in any econometric analysis, however.
} 
In practice, matching responses for an individual across surveys is not perfect. Because the CPS is a household-based survey, there are no person-specific identifiers that would enable the researcher to do the match directly. Moreover, individuals who move are not followed. The basic framework for matching people involves matching household identifiers and then matching individuals within the household according to their characteristics. On average, roughly two-thirds of those eligible to be matched actually are matched. ${ }^{12}$ Madrian and Lefgren (1999) describe alternative methods for conducting the match; we have adopted their preferred method.

\section{Health and Retirement Survey (HRS)}

The HRS is the premier data set to study aging issues in the U.S. The HRS began in 1992 as a longitudinal survey of individuals aged 51 to 61 (born between 1931 and 1941) and their spouses, with re-interviews of these 12,652 respondents every two years. Seven waves of the data, covering the years 1992 to 2004 , are now available. ${ }^{13}$ Starting in 1998 , the HRS was expanded to include all birth cohorts born prior to 1948. The HRS contains a wealth of information on employment, health, assets and income, demographics, family structure and transfers, and expectations. Importantly, the HRS also contains data on state of residence. ${ }^{14}$

As the HRS is conducted biennially, we look at retirement transitions and benefit receipt between survey waves. We define a retirement transition to have occurred when the respondent was working at the previous survey wave and retired by the survey date, based on self-reported

\footnotetext{
${ }^{12}$ This potentially creates a sample selection problem because individuals who retire then move will be included among the unmatched. Issues such as this highlight the importance of using different data sets, since the regular March CPS and HRS samples are not affected by this problem.

${ }^{13}$ Only the preliminary release of 2004 data is available at the current time.

${ }^{14}$ Access to these data is restricted to protect respondents' confidentiality, but we have received permission to access the state identifiers through the National Bureau of Economic Research (NBER), which has a standing restricted data agreement with the HRS.
} 
labor force status. ${ }^{15}$ UI receipt is identified based on questions about unemployment compensation received in the year before the survey (in odd-numbered years). Our measure misses instances of UI receipt that fall entirely within even-numbered years; thus, descriptive statistics and regression estimates are understated and our results should be interpreted accordingly. SS receipt is identified in a similar manner. Unfortunately, the HRS is not welldesigned to capture spells of unemployment between waves; thus, we do not conduct any analysis of unemployment using the HRS. ${ }^{16}$

\section{Empirical Strategy}

Our empirical analysis proceeds in two parts. The first question we examine is how labor market conditions affect retirement. To assess this, we estimate regressions of the following form for our three data sets:

$$
\text { retire }_{\text {iast }}=\beta_{0}+\beta_{1} \text { unemrate }_{s t}+\beta_{2} X_{i s t}+\gamma_{a}+\gamma_{s}+\gamma_{t}+\varepsilon_{\text {ist }}
$$

In this specification, retire is a dummy equal to 1 if individual $\mathrm{i}$, at age a, living in state $\mathrm{s}$, at time $\mathrm{t}$ retires and unemrate $_{s t}$ is the unemployment rate in that state and year. ${ }^{17}$ As described earlier, each of our data sources capture a retirement transition in a different way. For the remainder of the paper, we ignore those distinctions and simply refer to a retirement transition as a generic concept. In each case, we restrict our analysis to individuals who are in the labor force at time $\mathrm{t}-1$ and consider their decision to retire in the current period $\mathrm{t}$.

\footnotetext{
${ }^{15}$ Workers may select multiple labor force status codes. In our analysis, any individual who identifies himself as simultaneously working and retired is treated as working. Individuals who exit the labor force to disability or homemaker status (but do not explicitly label themselves as retired) are also treated as retired.

${ }^{16}$ The survey asks about unemployment on the survey date, but has no general question asked of non-working respondents about whether the individual spent time looking for work since the previous wave.

${ }^{17}$ To measure the labor market conditions facing older workers as accurately as possible, one might like to use an age-specific unemployment rate. Unfortunately, the relatively small sample sizes in the CPS in smaller states do not allow for this to be reliably estimated at the state level.
} 
Here and elsewhere in the model, $X$ represents personal characteristics of the individual (race, education, marital status, and the presence of children under age 18), $\gamma_{\mathrm{s}}$ represents statespecific fixed effects, $\gamma_{t}$ represents year-specific fixed effects, and $\gamma_{a}$ represents age-specific fixed effects. These age fixed effects incorporate the different retirement propensities of individuals at different ages. Including them essentially converts this model into a discrete-time proportional hazards model of retirement, where the estimated values of $\gamma_{\mathrm{a}}$ at each specific age represent the baseline hazard. Models of retirement transitions of this type are estimated in Coile and Levine (2006), Coile (2004a, 2004b) and Coile and Gruber (forthcoming). We estimate our regressions as linear probability models, but find results to be quite similar if we use probit models instead.

If unemployment acts as a constraint limiting the ability of older workers to remain in the labor force, we would expect the $\beta_{1}$ coefficient to be positive. To verify that this coefficient is picking up a causal effect of unemployment on retirement transitions, we estimate alternate versions of equation (1) where the dependent variable is defined as retirement accompanied by a period of unemployment and as retirement with UI receipt. If a higher unemployment rate raises the probability of retirement, then we would expect it to also raise the probability of retiring with a period of unemployment and retiring with UI receipt. Furthermore, to explore whether labor market conditions affect the take-up of other sources of retirement income, we estimate additional alternative versions of equation (1) where the dependent variable is retirement with SS receipt or retirement with receipt of pension income. ${ }^{18}$ Finally, for all specifications, we explore

\footnotetext{
${ }^{18}$ Because we cannot directly identify receipt of SSDI income in the CPS, as explained above, we cannot use the CPS to explore whether DI receipt is cyclical. We can identify DI receipt in the HRS and find no evidence that it is cyclical, although this may be due in part to small sample sizes. Interestingly, Duggan et. al. (2006) find that takeup of the Veterans Affair's Disability Compensation program is cyclical.
} 
whether the effect of labor market conditions on retirement varies by age, by interacting the unemployment rate with age group dummies. ${ }^{19}$

The second question we address is whether a more generous UI system reduces the likelihood of transitions into retirement. We define the generosity of a state's UI system along two dimensions - the benefit level and ease of meeting monetary eligibility requirements. ${ }^{20}$ As we described earlier, an older unemployed worker may search longer if that worker is receiving a larger UI benefit, which may forestall the decision to retire; if suitable employment can be found, that retirement decision may be prolonged even further. Thus one hypothesis we seek to test is the potential negative relationship between higher UI benefit levels and the likelihood of a retirement transition. In addition, the UI system is more likely to affect retirement transitions if a larger share of workers is monetarily eligible for UI benefits, so we test this hypothesis as well.

To this end, we estimate models of the form:

$$
\begin{gathered}
\text { retire }_{\text {iast }}=\beta_{0}+\beta_{1} \log (\max \text { weeklybenefit })_{s t}+\beta_{2} \text { shareeligible }_{s t}+\beta_{3} \text { unemrate }_{\text {st }} \\
+\beta_{4} X_{i s t}+\gamma_{a}+\gamma_{s}+\gamma_{t}+\varepsilon_{i s t}
\end{gathered}
$$

where maxweeklybenefit is the maximum weekly benefit amount that a UI recipient can collect in

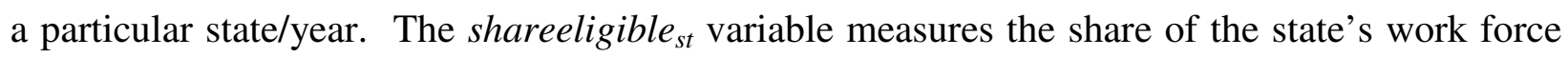

\footnotetext{
19 A broader life-cycle model would include kinks in the intertemporal budget constraint introduced by the availability of retirement benefits at particular ages as well as other program rules, such as the work eligibility requirements and benefit formulas for Social Security retired worker and disability insurance benefits. Estimation of such a structural model is beyond the scope of this paper, though we note in the conclusion that a fruitful area for future research is to build a retirement model that incorporates the role of labor market constraints along with other factors that have been more extensively studied, such as Social Security incentives.
}

${ }^{20}$ Although benefit levels and monetary eligibility rules are probably the most important components of the UI program, there are other program provisions that may play a role in retirement transitions. For instance, beginning in the mid-1990s, a handful of states began to offer a "self-employment assistance" program that enables UI recipients to receive UI benefits in a lump-sum in order to start up a small business. Since older workers transitioning to retirement may find a period of self-employment desirable, such a program may have relevance for them. Nevertheless, our analysis of these programs found no systematic relationship. In addition, rules allowing workers to collect UI while searching for part-time work only may also enhance the program's usefulness to some older workers. Unfortunately, our survey of the regulations only turned up documentation on state differences in these policies beginning in the mid-1990s. Before that, we were unable to verify what states had what types of policies in this regard. As a result, we are unable to examine this possibility in our econometric analysis. 
that satisfies the monetary eligibility requirements for UI benefit receipt at time t. Since this will depend not only on the state's eligibility rules but also on the characteristics of workers in the state, we use a simulated measure of eligibility that is generated by running a common sample of individuals through the eligibility rules in each state and year. ${ }^{21}$ This approach is useful in that it provides a systematic measure of the generosity of a state's eligibility rules at a point in time and is unrelated to the characteristics of the individual.

This model represents a reduced form specification of a structural model where the retirement rate depends upon the replacement rate than an individual worker receives. Since an individual's replacement rate is endogenous to his past labor market activity, the maximum weekly benefit amount would serve as an appropriate instrumental variable. This reduced form approach is a more parsimonious specification of this relationship that focuses on the plausibly exogenous variation in a state-set policy parameter. ${ }^{22,23}$

There are, of course, other potential sources of bias in this parameter estimate. Since our approach relies on state-specific variability, geographical differences in labor market attributes may be related to success in the labor market and to the process of setting maximum benefit

\footnotetext{
${ }^{21}$ Specifically, we use a random sample of 5,000 March CPS respondents from 1979 to 2003 who spent time looking for work last year and were unemployed for less than 26 weeks on the survey date (to avoid those that had exhausted their benefits). The mean rate of monetary eligibility for this sample (73\%) is based on all unemployed workers, not just job losers, whose rate of eligibility would be higher. See Levine (forthcoming) for details.

22 "Policy endogeneity" is one criticism that is sometimes made in models like this (Besley and Case, 2000). The potential problem is that the state may set its policies in response to labor market conditions, perhaps lowering maximum weekly benefits when unemployment rates are high to save money. If retirements increase during recessions, this would generate a spurious negative relationship between maximum weekly benefits and retirements. Although this is a reasonable concern, Levine (forthcoming) shows that states tend to respond to the financial stress that a recession places on the UI system by raising taxes rather than by lowering benefits.

${ }^{23}$ One can easily imagine that the UI system would be more important for certain workers, such as those who lack sufficient work history to qualify for Social Security benefits or who are in poor health. Unfortunately, the CPS lacks the data necessary to pursue these hypotheses. One could theoretically do so in the HRS, but since our HRS estimates are generally much less precise than our CPS estimates due to smaller sample sizes, as we discuss below, we feel that pursuing this would be unlikely to generate significant results.
} 
amounts. To the extent that these differences are long-standing in nature, we can account for them by including state-fixed effects in our model. Similarly, national trends over time may be related to both retirement patterns as well as the generosity of UI benefits, so we also include year-specific fixed effects. Thus, our identification is based on variation in the maximum weekly benefit amount within states over time and our key identifying assumption is that such changes are exogenous to retirement behavior.

\section{RESULTS}

\section{A. Descriptive Analysis}

In this part of the paper we use the alternative datasets at our disposal to describe the roles that unemployment spells and unemployment insurance receipt play in retirement transitions. Figure 1 shows the annual retirement hazard for workers age 55 to 69 over the past twenty-five years, with shading to indicate the timing of recessions. ${ }^{24}$ Overall, the figure shows a recent downward trend in retirement. Any possible increase in retirement during recession years is swamped by the general downward trend and noise in the year-to-year estimates. The HRS annual retirement rate is somewhat noisier, as may be expected given the smaller sample size. ${ }^{25}$

Figure 2 examines the relative frequency of various paths to retirement in the March CPS by showing the share of retirements that occur with unemployment, with UI receipt, with SS receipt, and with pension receipt. The share with SS receipt is quite high, at about 45 percent, and would naturally be much higher if we restricted the sample to only those workers age 62 and

\footnotetext{
${ }^{24}$ The definitions of when a recession begins and ends are based on the determination of the National Bureau of Economic Research and are based on movements in GDP. It is common for labor market peaks and troughs to lag behind the cyclical movements in GDP.

${ }^{25}$ Note that the retirement hazard for the HRS presented in Figure 1 is the annual retirement hazard. In Table 1 and the empirical analysis, retirement is between waves of the survey (over a two-year period), so the mean retirement rate is naturally much higher.
} 
above. As in Figure 1, there is no obvious increase in the frequency of retirement with SS receipt during recessions. This does not rule out the possibility that labor market conditions affect SS take-up, however; since the majority of SS take-up is not driven by labor market conditions, any such effect would likely be too small to see in the overall data. The share retiring with pension receipt is also fairly high, at 30 percent, and is roughly constant over the period. The share of workers retiring with a spell of unemployment or of UI receipt, by contrast, does display a cyclical pattern, with the spikes often occurring just after the official end of the recession. Another interesting thing to note from Figure 2 is that twice as many workers retire with a spell of unemployment, roughly 12 percent over the years, as do with a spell of UI receipt.

More direct information on the extent to which spells of unemployment are accompanied by UI receipt is shown in Table 1. Approximately 10 to 12 percent of such transitions include a spell of unemployment and about 6 to 7 percent include a spell of UI receipt. It is important to note, however, that only 3 to 5 percent of retirements included a spell of unemployment along with UI receipt. This means that a reasonably large number of older workers appear to transition to retirement with no unemployment, but still manage to collect UI benefits. Alternatively, the labor market measures available to us over the relevant time window may not be sufficient to capture all periods of unemployment.

The frequency of retirement transitions that involve spells of UI receipt, reported in Table 1, is lower in the U.S. than in other developed nations, but not dramatically so. In the U.S., this figure is 6 to 7 percent. This is essentially the same as in Sweden (Palme and Svensson, 2004), only slightly lower than in Belgium (Dellis et. al., 2004), and about one-third as large as in France and Germany (Mathieu and Blanchet, 2004; Borsch-Supan et. al., 2004). 
The lower panel of the table presents comparable statistics for the subsample of workers aged 62-65. Although retirement rates and, particularly, Social Security receipt are higher at these ages, the remainder of the results is comparable to those for the full sample of workers age $55-69 .^{26}$

\section{B. Empirical Analysis}

Tables $2 \mathrm{~A}$ and $2 \mathrm{~B}$ present the results of estimating equation (1). The coefficients and standard errors shown on the table have been multiplied by 10 , so that these numbers reflect the effect of a 10 percentage point increase in the unemployment rate. In our discussion, we focus on the effect of a 3 percentage point increase, which corresponds roughly from moving from a period of expansion to recession. All specifications include demographic variables and age, state, and time fixed effects, as detailed above. Our models are estimated as linear probability models.

The second row on these tables shows the effect of the unemployment rate on retirement. In the March CPS results shown in Column 1 of Table 2A, a 3 percentage point increase raises the probability of retirement by .006 percentage points, or 4.6 percent relative to the mean retirement rate of 13 percent. The effect is statistically significant. The coefficient from the matched March CPS in Column 6 is very similar and is statistically significant at the 10 percent level, reflecting the smaller sample size in those data. The coefficient from the HRS in Column 1 of Table $2 \mathrm{~B}$ is somewhat larger, indicating a 13 percent increase relative to the mean retirement rate, and is significant at the 10 percent level.

To better understand the magnitude of our coefficients, we compare them to estimates from previous studies looking at the effect of other factors on retirement. We find that these estimates are fairly similar in magnitude to the effect of moderate changes in financial incentives from SS

\footnotetext{
${ }^{26}$ One discrepancy across data sets is that SS receipt is considerably lower in the March CPS than the other two sources of data. Again, we believe the reason for this is that the definition of "retirement" in the March CPS includes transitions for individuals who are less attached to the labor market in the first place.
} 
and pensions. For example, Coile and Gruber (forthcoming) estimate that a $\$ 10,000$ increase in SS wealth raises the probability of retirement by 4 percent relative to the mean retirement rate and that a $\$ 1,000$ increase in the return to additional work through the SS and pension systems lowers retirement by 1 percent.

Comparing these estimates to the impact of health shocks is complicated by the fact that studies examining their impact concentrate on the effect on the individuals experiencing the shock rather than the aggregated effect that relies on an increase in the risk of experiencing such a shock. The latter approach is consistent with our analysis of labor market shocks. As a point of comparison, Coile (2004b) finds that a heart attack, stroke, or new cancer diagnosis raises the probability of retirement by 87 percent relative to the mean for men and by 51 percent for women, but these events occur for 6.7 percent of men and 5 percent of women over a two year period. This means that the aggregate impact associated with the threat of such a health shock is a 6 percent reduction in retirement rates relative to the mean for men and a 3 percent reduction for women. These are comparable to our estimates of the impact of a recession.

The remaining columns in these tables explore whether a higher unemployment rate is associated with a higher probability of retirement accompanied by unemployment, UI receipt, SS receipt, and pension receipt. Columns 2 and 3 (March CPS), Columns 6 and 7 (matched March CPS) in Table 2A and Column 2 in Table 2B (HRS) focus on the probability of retirement with unemployment and retirement with UI receipt. We view these specifications as an important way to check that our analysis is measuring a causal effect of unemployment on retirement rather than some spurious effect. In each case, the results support our interpretation. Our coefficient estimates are highly significant and much larger in magnitude, relative to the mean probability of such transitions in the sample as a whole, than those reported above. The remaining columns in these 
tables test whether higher unemployment results in more transitions to retirement with SS or pension receipt. We find positive and generally significant coefficients across the three data sets, indicating that workers with access to retirement benefits may use them to help overcome unemployment-related income loss.

The lower panel on Tables $2 \mathrm{~A}$ and $2 \mathrm{~B}$ allows the effect of the unemployment rate on retirement to vary by age by including the unemployment rate as well as interactions between it and various age group dummies $(58-60,61,62-64,65-67$, and 68-69; implicitly, 55-57 is the omitted group). ${ }^{27}$ Here we find a striking pattern. In the general retirement models (Columns 1 and 6 of Table 2A and Column 1 of Table 2B), the unemployment rate coefficient is insignificant in all three data sets, as is the interaction with the age 58-60 dummy. Starting at age 62, however, the interaction terms become positive and significant in both CPS data sets. ${ }^{28}$ These results indicate that the ability of workers to respond to labor market shocks by retiring is highly dependent on their access to SS benefits. Point estimates in the HRS are similar, but more imprecisely estimated due to the small sample size. The remaining columns of the lower panels of these tables further confirm that these effects by age are driven by transitions that include a spell of unemployment and UI receipt. Moreover, retirements that include receipt of SS and pension benefits also rise beginning at age 62 when a recession hits. All of this evidence suggests that workers rely on their ability to access SS when they become eligible for those benefits as a form of income support when they lose their jobs.

\footnotetext{
${ }^{27}$ We have also estimated models where the unemployment rate is interacted with single age dummies. The results were analogous to those described here, but somewhat noisier since there are fewer people in each single age cell.

${ }^{28}$ There is also some evidence that this effect may begin at age 61. This may occur because individuals who lose their jobs during a recession are able to make do with UI benefits or their own savings for a short time before SS benefit eligibility. Alternatively, this may result from the difficulties in precisely estimating a worker's age at the time of retirement.
} 
In Table 3, we run regressions separately in the two CPS data sets for men and women and by education group. In our basic specification, we find consistently stronger effects of the unemployment rate on retirement for women and for high school graduates. When we add age interactions, it is evident that the unemployment rate affects retirement only starting at age 61 or 62 for most groups (high school graduates, high school dropouts, men, and women); however, the age interactions are too imprecisely measured to draw any strong conclusions about whether these effects are larger for one group or another.

We know from Tables $2 \mathrm{~A}$ and $2 \mathrm{~B}$ that labor market constraints affect retirement transitions, but what role do UI incentives play? We explore this question in Table 4. The specifications displayed here parallel those on Tables $2 \mathrm{~A}$ and $2 \mathrm{~B}$, except that we add two right hand side variables to capture the generosity of the UI system, the log of the maximum weekly UI benefit amount and the simulated share of workers eligible for UI. ${ }^{29}$ We expect a negative effect of UI benefits on retirement, as a more generous UI benefit may lead workers to take-up UI and delay onset of retirement and benefit claiming for the duration of UI receipt and also may allow workers the time to find a new job, delaying retirement still further. We also expect a negative effect of the share eligible on retirement, as fewer workers may transition to retirement if more of them are eligible for UI.

In the first panel, we fail to find a consistent negative and significant effect of either the UI benefit level or share eligible for UI on retirement. When we interact these measures of UI generosity with age, we do find the expected negative coefficient on these interaction terms

\footnotetext{
${ }^{29}$ In keeping with our focus on retirement, we continue to define the dependent variable as a transition to retirement. Alternatively, looking at the effect of UI on SS claiming could be of interest because claiming may be considered an alternative retirement definition and because there may be program interactions between UI and SS. Program interactions are an important and understudied area; see Neumark and Powers (2005) and Mitchell and Phillips (2000) for two notable exceptions. We conducted such an analysis, limiting the sample to those age 61 and above for whom SS claiming is an option, but failed to find statistically significant effects of UI generosity on claiming.
} 
starting at age 62 in the two CPS data sets. However, these coefficients are sometimes insignificant and imply relatively small effects of the UI system on retirement, once the main effect is added to the interaction term. For example, the total effect of a 10 percent increase in the maximum weekly benefit amount in the matched March CPS is to lower retirement by .0048, or about 2 percent relative to the mean retirement rate in this age group, but the total effect in the March CPS and HRS is near zero. For the share eligible, the total effect at age 62 is negative in both the March CPS and matched March CPS, though the age 62 interaction is significant only in the former. Overall, we find weak evidence at best that more generous UI benefits enable older workers to delay retirement. $^{30}$

The results in Table 4 are somewhat puzzling because past work has found that UI incentives have played a significant role in explaining take-up rates and unemployment durations. Do these incentives matter less for older workers or is the impact on retirement simply different than that found for these other behaviors? To investigate this question, we used the March CPS data to estimate models that approximate UI take-up and unemployment duration. We relate the $\log$ of the maximum weekly UI benefit in a respondent's state and year to an indicator of take-up (the likelihood of collecting UI among those who experience some unemployment) and an indicator of spell duration (weeks spent looking for work in the last calendar year among those experiencing some unemployment). ${ }^{31}$ We examine these outcomes for the same sample of 55-69

\footnotetext{
${ }^{30}$ It is plausible that the generosity of the UI system affects retirement transitions more when the unemployment rate is higher or when a larger fraction of workers is eligible for benefits. However, we find no evidence of this when we add an interaction between the unemployment rate and the UI benefit level or the share eligible to the model.

${ }^{31}$ Past work in this area has been able to identify take-up as the receipt of benefits among UI eligible workers, but we do not have access to UI eligibility. Similarly, duration models have typically taken advantage of data that enables the researcher to follow spells of unemployment in a hazard framework, but we do not have data of that form either. We only use the March CPS for this analysis because the matched March data has the same information with smaller sample sizes than the regular March CPS data. The HRS is not appropriate since it does not contain much information on unemployment.
} 
year old workers as we have been focusing on, but we also replicate the analysis for workers younger than that (age 21-54) to see if there is a difference between age groups.

The results of this analysis are presented in Table 5. For younger workers, we find that benefit generosity and more lenient eligibility rules are both positively associated with UI receipt, while only the UI benefit level is positively associated with the duration of unemployment, which is all consistent with the previous literature and our expectations. For older workers, however, the effect of both measures of UI generosity on receipt is negative and insignificant, while the effect of UI benefit level on duration is positive, significant, and larger than for younger workers. We believe the duration results may be consistent with a story where older workers on UI do not look as hard for new jobs as younger workers; for them, UI benefits may be simply a source of income, rather than a means to make a better job match. Regardless, the fact that UI receipt does not seem to be affected by UI generosity for older workers is consistent with the lack of a retirement response to such changes.

\section{DISCUSSION AND CONCLUSIONS}

This study has explored how unemployment affects retirement and whether the UI system and access to SS affect workers' responses to labor market shocks. We have several principal findings. First, we find that retirement transitions are cyclically sensitive. The magnitudes of these effects are similar to those associated with moderate changes in financial incentives to retire and to the threat of a health shock to which older workers are exposed. Second, although we predicted that more generous UI benefits would be associated with a reduced probability of retirement, we find no consistent evidence of this. Finally, we find that SS interacts with labor market conditions in affecting retirement transitions, as the effect of the unemployment rate on retirement transitions 
appears only as workers near or reach the age of eligibility for SS benefits. Overall, our findings indicate that older workers may rely more on SS than on UI to help them weather labor market shocks. For these workers, the SS system may be a better source of protection against the income loss associated with unemployment than the UI system.

How do we explain our finding that older workers respond more to SS than to UI in responding to labor market shocks? In answering this, it is useful to recall that the UI system has two goals, to provide consumption-smoothing benefits for workers facing lost earnings due to unemployment and to give workers the means to find a better job match. The second goal is clearly less important for older workers than their younger counterparts, since older workers have fewer years to benefit from improved match quality and are less likely have good jobs available to them in any event.

In terms of consumption smoothing, SS may provide a more attractive means of accomplishing this than UI. First, UI benefit receipt is typically limited to 6 months, while SS benefits are received until death. Second, UI benefit receipt involves transactions costs that SS does not, namely the requirement to report search activity to the UI office and the stigma associated with UI receipt. Moreover, some workers may be reluctant to apply for UI benefits if they have no intention of searching for a new job. This may help explain why workers may not claim UI and go straight to SS, thereby passing up the opportunity to add perhaps $\$ 5,000$ to $\$ 10,000$ to their lifetime wealth.

We believe that the primary contribution of this paper is to raise awareness that labor market conditions may be important determinants of retirement transitions along with other factors that have previously received more attention in the literature, such as health status, health insurance access, financial incentives from SS and private pensions, and couples' retirement decision- 
making. Naturally, there may be interactions between these various factors, so that, for example, the consequences of job loss for those in poor health may be even greater because new jobs may be even harder to find. We believe that exploring these interactions is a fruitful area for future research. 


\section{REFERENCES}

Anderson, Patricia M. and Bruce D. Meyer. "Unemployment Insurance Takeup Rates and the After-Tax Value of Benefits. Quarterly Journal of Economics. Vol. 112, No. 3. (August 1997), pp. 913-937.

Baker, Michael, Mark Stabile, and Catherine Deri. "What Do Self-Reported, Objective Measures of Health Measure?" Journal of Human Resources Vol 39, No. 4 (Fall 2004). Pp. 1067-1093.

Besley, Timothy and Anne Case. "Unnatural Experiments? Estimating the Incidence of Endogenous Policies.” 2000. Economic Journal Vol. 110, No. 467 (November 2000). pp. F672F694.

Blau, David M. and Donna B. Gilleskie. "Retiree Health Insurance and the Labor Force Behavior of Older Men in the 1990s." Review of Economics and Statistics, Vol. 83, No. 1 (February 2001). pp. 64-80.

Borsch-Supan, Axel, Reinhold Schnabel, Simone Kohnz, and Giovanni Mastrobuoni. "MicroModeling of Retirement Decisions in Germany," pp. 285-344 in Jonathan Gruber and David A. Wise (eds.), Social Security Programs and Retirement Across the World: Micro-Estimation. Chicago: University of Chicago Press, 2004.

Chan, Sewin and Ann Huff Stevens. "Employment and Retirement Following a Late-Career Job Loss.” American Economic Review, Vol. 89, No. 2 (May 1999), pp. 211-216.

Chan, Sewin and Ann Huff Stevens. "How Does Job Loss Affect the Timing of Retirement?" Contributions to Economic Analysis \& Policy, Vol. 3, No. 1 (2004), article 5.

Chan, Sewin and Ann Huff Stevens. "Job Loss and Employment Patterns of Older Workers." Journal of Labor Economics, Vol. 19, No. 2 (April 2001), pp. 484-521.

Coile, Courtney C. "Retirement Incentives and Couples' Retirement Decisions," Topics in Economic Analysis \& Policy. Vol. 4, No. 1 (2004a). article 17.

Coile, Courtney C. Health Shocks and Couples' Labor Supply Decisions." National Bureau of Economic Research Working Paper 10810, October 2004b.

Coile, Courtney, Peter Diamond, Jonathan Gruber, Alain Jousten. "Delays in Claiming Social Security Benefits.” Journal of Public Economics, Vol. 84, No. 3 (June 2002). pp 357-385.

Coile, Courtney C. and Jonathan Gruber. "Future Social Security Entitlements and the Retirement Decision." Review of Economics and Statistics. Forthcoming.

Coile, Courtney C. and Phillip B. Levine. "Bulls, Bears, and Retirement Behavior." Industrial and Labor Relations Review. Vol. 59, No. 3 (April 2006). pp. 408-429. 
Dellis, Arnaud, Raphael Desmet, Alain Jousten, and Sergio Perelman. "Micro-Modeling of Retirement in Belgium," pp. 41-98 in Jonathan Gruber and David A. Wise (eds.), Social Security Programs and Retirement Across the World: Micro-Estimation. Chicago: University of Chicago Press, 2004.

Devereaux, Paul J. "The Cyclicality of Real Wages within Employer-Employee Matches." Industrial and Labor Relations Review. Vol. 54, No. 4 (July 2001). pp 835-850.

Duggan, Mark, Robert Rosenheck, and Perry Singleton. "Federal Policy and the Rise in Disability Enrollment: Evidence for the VA's Disability Compensation Program," NBER Working Paper \#12323, June 2006.

Dwyer, Debra S. and Olivia S. Mitchell. "Health Problems as Determinants of Retirement: Are Self-Rated Measures Endogenous?" Journal of Health Economics, Vol. 18, No. 2 (April 1999). pp.173-193.

Farber, Henry S. "What do we know about Job Loss in the United States? Evidence from the Displaced Workers Survey, 1984-2004" Princeton University, Industrial Relations Section Working Paper \#498. January 2005.

Gruber, Jonathan and Julie Cullen. "Does Unemployment Insurance Crowd Out Spousal Labor Suuply?” Journal of Labor Economics, Vol. 18, No. 3 (July 2000), pp. 546-572.

Gruber, Jonathan and Brigitte Madrian. "Health Insurance Availability and the Retirement Decision," American Economic Review. Vol. 85, No. 4 (September 1995). pp 938-948.

Hallberg, Daniel. "Economic Fluctuations and the Retirement of Elderly Workers." Unpublished manuscript. May 2006.

Hamermesh, Daniel S. Unemployment Insurance and the Older American. Kalamazoo, Michigan: The W. E. Upjohn Institute for Employment Research. 1980.

Hotz, V. Joseph and John Karl Sholz. "Measuring Employment and Income for Low-Income Populations with Administrative and Survey Data," in Michele Ver Ploeg, Robert A. Moffitt, and Constance F. Citro (eds.) Studies of Welfare Populations: Data Collection and Research Issues. Washington, DC: National Academy Press. 2002.

Hutchens, Robert. "Social Security Benefits and Employer Behavior: Evaluating Social Security Early Retirement Benefits as a Form of Unemployment Insurance," International Economics Review. Vol. 40, No. 3 (August 1999), pp. 659-678.

Hutchens, Robert and Louis Jacobson. "Unemployment Insurance and Older Workers: Pennsylvania 1970-1994.” Unpublished manuscript. April 2002. 
Krueger, Alan B. and Bruce D. Meyer. "Labor Supply Effects of Social Insurance," pp. 23272392 in Alan Auerbach and Martin Feldstein, (eds.) Handbook of Public Economics, Volume 4, Amsterdam: North-Holland, 2002.

Levine, Phillip B. "A Comparison of Contemporaneous and Retrospective Measures of Unemployment from the Current Population Survey." Monthly Labor Review, August 1993b, pp. 33-38.

Levine, Phillip B. 'Unemployment Insurance over the Business Cycle: Does it Meet Workers' Needs?" in Rebecca Blank, Sheldon Danziger, and Robert Shoeni (eds.), "Working and Poor: How Economic and Policy Changes Are Affecting Low-Wage Workers." New York: Russell Sage Foundation. Forthcoming.

Lundberg, Shelley. "The Added Worker Effect," Journal of Labor Economics, Vol. 3, No. 1, Part 1 (January 1985), pp. 11-37.

Madrian, Brigitte, and Lars John Lefgren. "A Note on Longitudinally Matching Current Population Survey (CPS) Respondents." National Bureau of Economic Research, technical working paper t0247, November 1999.

Mahieu, Ronan, and Didier Blanchet. "Estimating Models of Retirement on French Data," pp. 235-284 in Jonathan Gruber and David A. Wise (eds.), Social Security Programs and Retirement Across the World: Micro-Estimation. Chicago: University of Chicago Press, 2004.

Mitchell, Olivia S. and John R. Phillips. "Retirement Responses to Early Social Security Benefit Reductions.” National Bureau of Economic Research, working paper 7963, October 2000.

Mortensen, Dale T. "Job Search and Labor Market Analysis", pp. 849-919 in Orley C. Ashenfelter and Richard Layard (eds.), Handbook of Labor Economics. Amsterdam: North Holland. 1986.

Neumark, David and Elizabeth Powers. "The Supplemental Security Income Program and the Incentive to Claim Social Security Retirement Early," National Tax Journal Vol. 58, No. 1 (March 2005), pp 5-26.

Oshio, Takashi and Akiko Sat Oishi. "Social Security and Retirement in Japan: An Evaluation Using Micro-Data," pp. 399-460 in Jonathan Gruber and David A. Wise (eds.), Social Security Programs and Retirement Across the World: Micro-Estimation. Chicago: University of Chicago Press, 2004.

Palme, Marten, and Ingemar Svensson. "Income Security Programs and Retirement in Sweden," pp. 579-642 in Jonathan Gruber and David A. Wise (eds.), Social Security Programs and Retirement Across the World: Micro-Estimation. Chicago: University of Chicago Press, 2004. 
Rebick, Marcus E. "Social Security and Older Workers' Labor Market Responsiveness," in Rebecca M. Blank (ed.), Social Protection versus Economic Flexibility: Is There a Trade-Off?. Chicago: University of Chicago Press, 1994.

Stock, James H. and David A. Wise. "Pensions, the Option Value of Work, and Retirement," Econometrica, Vol. 58, No. 5 (September 1990). pp.1151-1180.

Spletzer, James R. "Reexamining the Added Worker Effect," Economic Inquiry Vol. 35, No. 2 (1997), pp 417-427.

U.S. Department of Labor, Employment and Training Administration. Comparison of State Unemployment Insurance Laws, 2005.

U.S. Department of Labor, Employment and Training Administration. Unemployment Insurance Financial Data (ET Handbook 394). Washington, DC: Government Printing Office, 2006. 


\begin{tabular}{|c|c|c|c|}
\hline & \multicolumn{3}{|c|}{ Matched } \\
\hline & March CPS & March CPS & HRS \\
\hline & \multicolumn{3}{|c|}{ Ages 55-69 } \\
\hline Retirement Rate & 13.0 & 11.5 & 19.7 \\
\hline$\%$ with Unemployment & 11.9 & 11.3 & --- \\
\hline$\%$ with UI Receipt & 6.1 & 7.3 & 4.6 \\
\hline$\%$ with Unemployment and UI & 3.3 & 4.9 & --- \\
\hline$\%$ with SS Receipt & 45.8 & 61.6 & 61.7 \\
\hline$\%$ with Unemployment and SS & 4.4 & 6.0 & --- \\
\hline$\%$ with Pension Receipt & 32.4 & 37.8 & 29.6 \\
\hline \multirow[t]{2}{*}{$\%$ with Unemployment and Pension } & 2.7 & 3.4 & --- \\
\hline & \multicolumn{3}{|c|}{ Ages $62-65$} \\
\hline Retirement Rate & 21.4 & 19.2 & 30.2 \\
\hline \% with Unemployment & 9.8 & 9.7 & --- \\
\hline$\%$ with UI Receipt & 6.0 & 6.9 & 4.3 \\
\hline$\%$ with Unemployment and UI & 3.2 & 4.3 & --- \\
\hline$\%$ with SS Receipt & 64.0 & 81.6 & 87.7 \\
\hline$\%$ with Unemployment and SS & 6.4 & 8.2 & --- \\
\hline$\%$ with Pension Receipt & 36.5 & 42.9 & 31.5 \\
\hline$\%$ with Unemployment and Pension & 2.8 & 3.3 & --- \\
\hline
\end{tabular}


Table 2A: The Role of Labor Market Conditions in Retirement Transitions, CPS Data (standard errors in parentheses)

\begin{tabular}{|c|c|c|c|c|c|c|c|c|c|c|}
\hline & \multicolumn{5}{|c|}{ "March CPS } & \multicolumn{5}{|c|}{ Matched March CPS } \\
\hline & $\begin{array}{l}\text { Retire } \\
(1)\end{array}$ & $\begin{array}{c}\text { Retire with } \\
\text { unemployment } \\
(2)\end{array}$ & $\begin{array}{c}\text { Retire with } \\
\text { UI Receipt } \\
\text { (3) }\end{array}$ & $\begin{array}{c}\text { Retire with } \\
\text { SS Receipt } \\
\text { (4) }\end{array}$ & $\begin{array}{l}\text { Retire with } \\
\text { Pension } \\
(5)\end{array}$ & $\begin{array}{l}\text { Retire } \\
(6)\end{array}$ & $\begin{array}{c}\text { Retire with } \\
\text { unemployment } \\
(7)\end{array}$ & $\begin{array}{c}\text { Retire with } \\
\text { UI Receipt } \\
(8)\end{array}$ & $\begin{array}{c}\text { Retire with } \\
\text { SS Receipt } \\
\text { (9) }\end{array}$ & $\begin{array}{c}\text { Retire with } \\
\text { Pension } \\
(10)\end{array}$ \\
\hline Mean of Dep. Variable & 0.130 & 0.016 & 0.008 & 0.060 & 0.042 & 0.116 & 0.013 & 0.008 & 0.071 & 0.044 \\
\hline Unemployment rate & $\begin{array}{c}0.0198 \\
(0.0078)\end{array}$ & $\begin{array}{c}0.0189 \\
(0.0025)\end{array}$ & $\begin{array}{c}0.0091 \\
(0.0018)\end{array}$ & $\begin{array}{c}0.0140 \\
(0.0060)\end{array}$ & $\begin{array}{c}0.0101 \\
(0.0051)\end{array}$ & $\begin{array}{c}0.0208 \\
(0.0122)\end{array}$ & $\begin{array}{c}0.0131 \\
(0.0058)\end{array}$ & $\begin{array}{c}0.0119 \\
(0.0037)\end{array}$ & $\begin{array}{c}0.0182 \\
(0.0086)\end{array}$ & $\begin{array}{c}0.0076 \\
(0.0060)\end{array}$ \\
\hline Number of Obs. & 278,641 & 278,641 & 278,641 & 278,641 & 278,641 & 82,115 & 82,115 & 82,115 & 82,115 & 82,115 \\
\hline Unemployment rate & $\begin{array}{l}-0.0001 \\
(0.0114)\end{array}$ & $\begin{array}{c}0.0110 \\
(0.0035)\end{array}$ & $\begin{array}{c}0.0043 \\
(0.0023)\end{array}$ & $\begin{array}{l}-0.0096 \\
(0.0060)\end{array}$ & $\begin{array}{l}-0.0004 \\
(0.0061)\end{array}$ & $\begin{array}{l}-0.0131 \\
(0.0124)\end{array}$ & $\begin{array}{c}0.0042 \\
(0.0059)\end{array}$ & $\begin{array}{c}0.0038 \\
(0.0034)\end{array}$ & $\begin{array}{l}-0.0183 \\
(0.0084)\end{array}$ & $\begin{array}{l}-0.0164 \\
(0.0068)\end{array}$ \\
\hline $\begin{array}{l}\text { Unemployment Rate* } \\
\text { Age 58-60 }\end{array}$ & $\begin{array}{c}0.0099 \\
(0.0096)\end{array}$ & $\begin{array}{c}0.007 \\
(0.0037)\end{array}$ & $\begin{array}{c}0.0068 \\
(0.0019)\end{array}$ & $\begin{array}{c}0.0039 \\
(0.0020)\end{array}$ & $\begin{array}{c}0.0025 \\
(0.0058)\end{array}$ & $\begin{array}{c}0.0063 \\
(0.0097)\end{array}$ & $\begin{array}{c}0.0075 \\
(0.0045)\end{array}$ & $\begin{array}{c}0.0061 \\
(0.0037)\end{array}$ & $\begin{array}{c}0.0027 \\
(0.0046)\end{array}$ & $\begin{array}{c}0.0069 \\
(0.0055)\end{array}$ \\
\hline $\begin{array}{l}\text { Unemployment Rate* } \\
\text { Age } 61\end{array}$ & $\begin{array}{c}0.0508 \\
(0.0119)\end{array}$ & $\begin{array}{c}0.0122 \\
(0.0053)\end{array}$ & $\begin{array}{c}0.0139 \\
(0.0044)\end{array}$ & $\begin{array}{c}0.0153 \\
(0.0052)\end{array}$ & $\begin{array}{c}0.0061 \\
(0.0064)\end{array}$ & $\begin{array}{c}0.0407 \\
(0.0230)\end{array}$ & $\begin{array}{c}0.0089 \\
(0.0073)\end{array}$ & $\begin{array}{c}0.0201 \\
(0.0077)\end{array}$ & $\begin{array}{c}0.0541 \\
(0.0243)\end{array}$ & $\begin{array}{c}0.0395 \\
(0.0201)\end{array}$ \\
\hline $\begin{array}{l}\text { Unemployment Rate* } \\
\text { Age } 62-64\end{array}$ & $\begin{array}{c}0.0517 \\
(0.0139)\end{array}$ & $\begin{array}{c}0.0129 \\
(0.0046)\end{array}$ & $\begin{array}{c}0.0132 \\
(0.0028)\end{array}$ & $\begin{array}{c}0.0509 \\
(0.0091)\end{array}$ & $\begin{array}{c}0.0237 \\
(0.0085)\end{array}$ & $\begin{array}{c}0.0584 \\
(0.0187)\end{array}$ & $\begin{array}{c}0.0269 \\
(0.0070)\end{array}$ & $\begin{array}{c}0.0237 \\
(0.0057)\end{array}$ & $\begin{array}{c}0.0706 \\
(0.0184)\end{array}$ & $\begin{array}{c}0.0496 \\
(0.0137)\end{array}$ \\
\hline $\begin{array}{l}\text { Unemployment Rate* } \\
\text { Age } 65-67\end{array}$ & $\begin{array}{c}0.1010 \\
(0.0170)\end{array}$ & $\begin{array}{c}0.0222 \\
(0.0056)\end{array}$ & $\begin{array}{c}0.0072 \\
(0.0037)\end{array}$ & $\begin{array}{c}0.1107 \\
(0.0169)\end{array}$ & $\begin{array}{c}0.0484 \\
(0.0129)\end{array}$ & $\begin{array}{c}0.1392 \\
(0.0219)\end{array}$ & $\begin{array}{c}0.0082 \\
(0.0075)\end{array}$ & $\begin{array}{c}0.0039 \\
(0.0072)\end{array}$ & $\begin{array}{c}0.1407 \\
(0.0208)\end{array}$ & $\begin{array}{c}0.0734 \\
(0.0164)\end{array}$ \\
\hline $\begin{array}{l}\text { Unemployment Rate* } \\
\text { Age } 68-69\end{array}$ & $\begin{array}{c}0.0257 \\
(0.0245)\end{array}$ & $\begin{array}{l}-0.0054 \\
(0.0057)\end{array}$ & $\begin{array}{l}-0.0004 \\
(0.0034)\end{array}$ & $\begin{array}{c}0.0377 \\
(0.0258)\end{array}$ & $\begin{array}{l}-0.0003 \\
(0.0173)\end{array}$ & $\begin{array}{c}0.1113 \\
(0.0335)\end{array}$ & $\begin{array}{c}0.0148 \\
(0.0111)\end{array}$ & $\begin{array}{c}0.0074 \\
(0.0097)\end{array}$ & $\begin{array}{c}0.1203 \\
(0.0373)\end{array}$ & $\begin{array}{c}0.0681 \\
(0.0268)\end{array}$ \\
\hline Number of Obs. & 278,641 & 278,641 & 278,641 & 278,641 & 278,641 & 82,115 & 82,115 & 82,115 & 82,115 & 82,115 \\
\hline
\end{tabular}

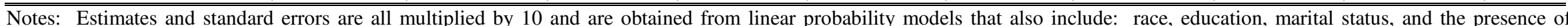
children under age 18, along with a full array of state and year dummy variables and age dummy variables for ages 56-69. Standard errors are clustered at the state level. 
Table 2B: The Role of Labor Market Conditions in Retirement Transitions, HRS Data (standard errors in parentheses)

\begin{tabular}{|c|c|c|c|c|}
\hline & $\begin{array}{l}\text { Retire } \\
(1)\end{array}$ & $\begin{array}{c}\text { Retire with UI } \\
\text { Receipt } \\
\text { (2) }\end{array}$ & $\begin{array}{c}\text { Retire with SS } \\
\text { Receipt } \\
\text { (3) }\end{array}$ & $\begin{array}{l}\text { Retire with } \\
\text { Pension } \\
(4)\end{array}$ \\
\hline Mean of Dep. Variable & 0.197 & 0.009 & 0.122 & 0.058 \\
\hline Unemployment rate & $\begin{array}{c}0.0868 \\
(0.0517)\end{array}$ & $\begin{array}{c}0.0134 \\
(0.0124)\end{array}$ & $\begin{array}{c}0.0357 \\
(0.0423)\end{array}$ & $\begin{array}{c}0.0467 \\
(0.0278)\end{array}$ \\
\hline Number of Obs. & 22,880 & 22,880 & 22,880 & 22,880 \\
\hline Unemployment rate & $\begin{array}{c}0.0564 \\
(0.0553)\end{array}$ & $\begin{array}{c}0.0087 \\
(0.0130)\end{array}$ & $\begin{array}{c}0.0222 \\
(0.0409)\end{array}$ & $\begin{array}{c}0.0211 \\
(0.0284)\end{array}$ \\
\hline $\begin{array}{l}\text { Unemployment Rate* } \\
\text { Age } 58-60\end{array}$ & $\begin{array}{c}0.0414 \\
(0.0415)\end{array}$ & $\begin{array}{l}-0.0113 \\
(0.0085)\end{array}$ & $\begin{array}{l}-0.0077 \\
(0.0151)\end{array}$ & $\begin{array}{c}0.0357 \\
(0.0222)\end{array}$ \\
\hline $\begin{array}{l}\text { Unemployment Rate* } \\
\text { Age } 61\end{array}$ & $\begin{array}{l}-0.0346 \\
(0.0702)\end{array}$ & $\begin{array}{c}0.0192 \\
(0.0228)\end{array}$ & $\begin{array}{l}-0.0111 \\
(0.0475)\end{array}$ & $\begin{array}{c}0.0281 \\
(0.0410)\end{array}$ \\
\hline $\begin{array}{l}\text { Unemployment Rate* } \\
\text { Age } 62-64\end{array}$ & $\begin{array}{c}0.0891 \\
(0.0581)\end{array}$ & $\begin{array}{c}0.0286 \\
(0.0132)\end{array}$ & $\begin{array}{c}0.0677 \\
(0.0488)\end{array}$ & $\begin{array}{c}0.0885 \\
(0.0370)\end{array}$ \\
\hline $\begin{array}{l}\text { Unemployment Rate* } \\
\text { Age } 65-67\end{array}$ & $\begin{array}{c}0.0421 \\
(0.0853)\end{array}$ & $\begin{array}{c}0.0089 \\
(0.0176)\end{array}$ & $\begin{array}{c}0.0373 \\
(0.0788)\end{array}$ & $\begin{array}{l}-0.0210 \\
(0.0547)\end{array}$ \\
\hline $\begin{array}{l}\text { Unemployment Rate* } \\
\text { Age } 68-69\end{array}$ & $\begin{array}{c}0.0356 \\
(0.1432)\end{array}$ & $\begin{array}{c}0.0081 \\
(0.0151)\end{array}$ & $\begin{array}{c}0.0384 \\
(0.1389)\end{array}$ & $\begin{array}{l}-0.1094 \\
(0.0850)\end{array}$ \\
\hline Number of Obs. & 22,880 & 22,880 & 22,880 & 22,880 \\
\hline
\end{tabular}


Table 3: The Role of Labor Market Conditions in Retirement Transitions by Demographic Group, CPS Data (standard errors in parentheses)

\begin{tabular}{|c|c|c|c|c|c|c|c|c|c|c|}
\hline & \multicolumn{5}{|c|}{ March CPS } & \multicolumn{5}{|c|}{ Matched March CPS } \\
\hline & $\begin{array}{c}\text { Men } \\
(1)\end{array}$ & $\begin{array}{l}\text { Women } \\
\text { (2) }\end{array}$ & $\begin{array}{l}\text { HS Dropout } \\
\text { (3) }\end{array}$ & $\begin{array}{l}\text { HS Grad } \\
\text { (4) }\end{array}$ & $\begin{array}{c}\text { Some College }+ \\
(5)\end{array}$ & $\begin{array}{c}\text { Men } \\
(1)\end{array}$ & $\begin{array}{l}\text { Women } \\
\text { (2) }\end{array}$ & $\begin{array}{l}\text { HS Dropout } \\
\text { (3) }\end{array}$ & $\begin{array}{l}\text { HS Grad } \\
\text { (4) }\end{array}$ & $\begin{array}{c}\text { Some College }+ \\
\text { (5) }\end{array}$ \\
\hline Mean of Dep. Variable & 0.119 & 0.144 & 0.163 & 0.134 & 0.111 & 0.089 & 0.107 & 0.140 & 0.102 & 0.077 \\
\hline Unemployment rate & $\begin{array}{c}0.0087 \\
(0.0093)\end{array}$ & $\begin{array}{c}0.0365 \\
(0.0112)\end{array}$ & $\begin{array}{c}-0.006 \\
(0.0142)\end{array}$ & $\begin{array}{c}0.0410 \\
(0.0137)\end{array}$ & $\begin{array}{c}0.0048 \\
(0.0128)\end{array}$ & $\begin{array}{l}-0.0020 \\
(0.0120)\end{array}$ & $\begin{array}{c}0.0507 \\
(0.0196)\end{array}$ & $\begin{array}{l}-0.0120 \\
(0.0312)\end{array}$ & $\begin{array}{c}0.0324 \\
(0.0222)\end{array}$ & $\begin{array}{c}0.0216 \\
(0.0166)\end{array}$ \\
\hline Number of Obs. & 155,578 & 123,063 & 62,435 & 101,672 & 114,534 & 45,983 & 36,132 & 17,193 & 30,946 & 33,976 \\
\hline Unemployment rate & $\begin{array}{l}-0.0244 \\
(0.0102)\end{array}$ & $\begin{array}{c}0.0162 \\
(0.0130)\end{array}$ & $\begin{array}{l}-0.0449 \\
(0.0170)\end{array}$ & $\begin{array}{c}0.0075 \\
(0.0125)\end{array}$ & $\begin{array}{l}-0.0047 \\
(0.0150)\end{array}$ & $\begin{array}{l}-0.0437 \\
(0.0133)\end{array}$ & $\begin{array}{c}0.0283 \\
(0.0215)\end{array}$ & $\begin{array}{l}-0.0537 \\
(0.0293)\end{array}$ & $\begin{array}{l}-0.0073 \\
(0.0245)\end{array}$ & $\begin{array}{c}0.0099 \\
(0.0179)\end{array}$ \\
\hline $\begin{array}{l}\text { Unemployment Rate* } \\
\text { Age 58-60 }\end{array}$ & $\begin{array}{c}0.0097 \\
(0.0126)\end{array}$ & $\begin{array}{c}0.0108 \\
(0.0145)\end{array}$ & $\begin{array}{c}0.0179 \\
(0.0162)\end{array}$ & $\begin{array}{c}0.0167 \\
(0.0160)\end{array}$ & $\begin{array}{c}0.0017 \\
(0.0116)\end{array}$ & $\begin{array}{c}0.0084 \\
(0.0170)\end{array}$ & $\begin{array}{c}0.0042 \\
(0.0252)\end{array}$ & $\begin{array}{c}0.0158 \\
(0.0227)\end{array}$ & $\begin{array}{c}0.0208 \\
(0.0191)\end{array}$ & $\begin{array}{l}-0.0128 \\
(0.0154)\end{array}$ \\
\hline $\begin{array}{l}\text { Unemployment Rate* } \\
\text { Age } 61\end{array}$ & $\begin{array}{c}0.0467 \\
(0.0127)\end{array}$ & $\begin{array}{c}0.0587 \\
(0.0241)\end{array}$ & $\begin{array}{c}0.0847 \\
(0.0203)\end{array}$ & $\begin{array}{c}0.0458 \\
(0.0222)\end{array}$ & $\begin{array}{c}0.0276 \\
(0.0224)\end{array}$ & $\begin{array}{c}0.0574 \\
(0.0288)\end{array}$ & $\begin{array}{c}0.0177 \\
(0.0331)\end{array}$ & $\begin{array}{c}0.0082 \\
(0.0450)\end{array}$ & $\begin{array}{c}0.0270 \\
(0.0355)\end{array}$ & $\begin{array}{c}0.0604 \\
(0.0424)\end{array}$ \\
\hline $\begin{array}{l}\text { Unemployment Rate* } \\
\text { Age } 62-64\end{array}$ & $\begin{array}{c}0.0721 \\
(0.0150)\end{array}$ & $\begin{array}{c}0.0214 \\
(0.0172)\end{array}$ & $\begin{array}{c}0.0479 \\
(0.0248)\end{array}$ & $\begin{array}{c}0.0727 \\
(0.0223)\end{array}$ & $\begin{array}{c}0.0147 \\
(0.0159)\end{array}$ & $\begin{array}{c}0.0698 \\
(0.0199)\end{array}$ & $\begin{array}{c}0.0400 \\
(0.0279)\end{array}$ & $\begin{array}{c}0.0547 \\
(0.0322)\end{array}$ & $\begin{array}{c}0.1025 \\
(0.0325)\end{array}$ & $\begin{array}{l}-0.0142 \\
(0.0272)\end{array}$ \\
\hline $\begin{array}{l}\text { Unemployment Rate* } \\
\text { Age } 65-67\end{array}$ & $\begin{array}{c}0.1087 \\
(0.0201)\end{array}$ & $\begin{array}{c}0.0898 \\
(0.0251)\end{array}$ & $\begin{array}{c}0.1341 \\
(0.0298)\end{array}$ & $\begin{array}{c}0.1203 \\
(0.0294)\end{array}$ & $\begin{array}{c}0.0373 \\
(0.0288)\end{array}$ & $\begin{array}{c}0.1756 \\
(0.0299)\end{array}$ & $\begin{array}{c}0.0888 \\
(0.0346)\end{array}$ & $\begin{array}{c}0.2002 \\
(0.0371)\end{array}$ & $\begin{array}{c}0.1347 \\
(0.0377)\end{array}$ & $\begin{array}{c}0.0763 \\
(0.0469)\end{array}$ \\
\hline $\begin{array}{l}\text { Unemployment Rate* } \\
\text { Age } 68-69\end{array}$ & $\begin{array}{c}0.0476 \\
(0.0321)\end{array}$ & $\begin{array}{l}-0.0079 \\
(0.0382)\end{array}$ & $\begin{array}{c}0.0484 \\
(0.0573)\end{array}$ & $\begin{array}{c}0.0073 \\
(0.0498)\end{array}$ & $\begin{array}{c}0.0123 \\
(0.0333)\end{array}$ & $\begin{array}{c}0.1263 \\
(0.0533)\end{array}$ & $\begin{array}{c}0.0820 \\
(0.0556)\end{array}$ & $\begin{array}{c}0.1175 \\
(0.0845)\end{array}$ & $\begin{array}{c}0.0597 \\
(0.0598)\end{array}$ & $\begin{array}{c}0.1161 \\
(0.0655)\end{array}$ \\
\hline Number of Obs. & 155,578 & 123,063 & 62,435 & 101,672 & 114,534 & 45,983 & 36,132 & 17,193 & 30,946 & 33,976 \\
\hline
\end{tabular}

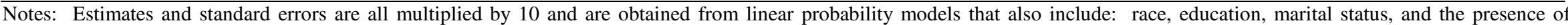
children under age 18, along with a full array of state and year dummy variables and age dummy variables for ages 56-69. Standard errors are clustered at the state level. 
Table 4: The Role of the Unemployment Insurance System in Retirement Transitions (standard errors in parentheses)

\begin{tabular}{|c|c|c|c|}
\hline & \multicolumn{3}{|c|}{ Matched March } \\
\hline & March CPS & CPS & HRS \\
\hline Log Max. UI Benefit & $\begin{array}{c}0.0194 \\
(0.0106)\end{array}$ & $\begin{array}{c}-0.0068 \\
(0.0097)\end{array}$ & $\begin{array}{c}0.0016 \\
(0.0460)\end{array}$ \\
\hline Simulated Monetary Eligibility (SME) & $\begin{array}{c}0.0057 \\
(0.0129)\end{array}$ & $\begin{array}{l}-0.0210 \\
(0.0277)\end{array}$ & $\begin{array}{c}-0.0002 \\
(0.0794)\end{array}$ \\
\hline Unemployment Rate & $\begin{array}{c}0.0170 \\
(0.0082)\end{array}$ & $\begin{array}{c}0.0213 \\
(0.0113)\end{array}$ & $\begin{array}{c}0.0863 \\
(0.0535)\end{array}$ \\
\hline Log Max. UI Benefit & $\begin{array}{c}0.0345 \\
(0.0123)\end{array}$ & $\begin{array}{c}-0.0007 \\
(0.0105)\end{array}$ & $\begin{array}{c}0.0380 \\
(0.0498)\end{array}$ \\
\hline Log Max. UI Benefit*Age 58-60 & $\begin{array}{l}-0.0061 \\
(0.0073)\end{array}$ & $\begin{array}{c}0.0124 \\
(0.0109)\end{array}$ & $\begin{array}{l}-0.0360 \\
(0.0294)\end{array}$ \\
\hline Log Max. UI Benefit*Age 61 & $\begin{array}{c}-0.0100 \\
(0.0127)\end{array}$ & $\begin{array}{l}-0.0470 \\
(0.0334)\end{array}$ & $\begin{array}{c}-0.0498 \\
(0.0489)\end{array}$ \\
\hline Log Max. UI Benefit*Age 62-64 & $\begin{array}{c}-0.0339 \\
(0.0145)\end{array}$ & $\begin{array}{c}-0.0362 \\
(0.0176)\end{array}$ & $\begin{array}{c}-0.0196 \\
(0.0379)\end{array}$ \\
\hline Log Max. UI Benefit*Age 65-67 & $\begin{array}{l}-0.0461 \\
(0.0156)\end{array}$ & $\begin{array}{l}-0.0210 \\
(0.0213)\end{array}$ & $\begin{array}{c}-0.0676 \\
(0.0516)\end{array}$ \\
\hline Log Max. UI Benefit*Age 68-69 & $\begin{array}{c}-0.0422 \\
(0.0230)\end{array}$ & $\begin{array}{c}0.0602 \\
(0.0342)\end{array}$ & $\begin{array}{c}-0.0748 \\
(0.0840)\end{array}$ \\
\hline Simulated Monetary Eligibility (SME) & $\begin{array}{c}0.0225 \\
(0.0185)\end{array}$ & $\begin{array}{c}-0.0090 \\
(0.0358)\end{array}$ & $\begin{array}{c}0.0571 \\
(0.0885)\end{array}$ \\
\hline SME*Age 58-60 & $\begin{array}{c}-0.0068 \\
(0.0148)\end{array}$ & $\begin{array}{c}0.0140 \\
(0.0313)\end{array}$ & $\begin{array}{l}-0.0919 \\
(0.0681)\end{array}$ \\
\hline SME*Age 61 & $\begin{array}{c}-0.0085 \\
(0.0384)\end{array}$ & $\begin{array}{c}0.0056 \\
(0.0728)\end{array}$ & $\begin{array}{c}0.0029 \\
(0.1130)\end{array}$ \\
\hline SME*Age 62-64 & $\begin{array}{c}-0.0775 \\
(0.0385)\end{array}$ & $\begin{array}{c}-0.0651 \\
(0.0490)\end{array}$ & $\begin{array}{l}-0.0051 \\
(0.0875)\end{array}$ \\
\hline SME*Age 65-67 & $\begin{array}{c}0.0054 \\
(0.0461)\end{array}$ & $\begin{array}{c}-0.0842 \\
(0.0638)\end{array}$ & $\begin{array}{c}-0.4292 \\
(0.1196)\end{array}$ \\
\hline SME*Age 68-69 & $\begin{array}{c}-0.0186 \\
(0.0490)\end{array}$ & $\begin{array}{c}0.0896 \\
(0.0822)\end{array}$ & $\begin{array}{c}0.2523 \\
(0.1933)\end{array}$ \\
\hline Unemployment Rate & $\begin{array}{c}0.0172 \\
(0.0082)\end{array}$ & $\begin{array}{c}0.0211 \\
(0.0113)\end{array}$ & $\begin{array}{r}0.0826 \\
(0.0534) \\
\end{array}$ \\
\hline
\end{tabular}

Notes: Estimates are obtained from linear probability models that also include: the unemployment rate, race, education, marital status, and the presence of children under age 18, along with a full array of state and year dummy variables and age dummy variables for ages 56-69. Standard errors are clustered at the state level. 
Table 5: The Impact of UI Generosity and Eligibility Rules on

UI Receipt and Duration of Unemployment, March CPS Data

(standard errors in parentheses)

\begin{tabular}{|c|c|c|c|c|}
\hline & \multicolumn{2}{|c|}{ Any UI Receipt in Calendar Year } & \multicolumn{2}{|c|}{ Weeks Unemployed in Calendar Year } \\
\hline & Age 21-54 & Age 55-69 & Age 21-54 & Age 55-69 \\
\hline Log Max UI Benefit & $\begin{array}{c}0.064 \\
(0.024)\end{array}$ & $\begin{array}{l}-0.020 \\
(0.035)\end{array}$ & $\begin{array}{c}0.096 \\
(0.030)\end{array}$ & $\begin{array}{c}0.237 \\
(0.100)\end{array}$ \\
\hline $\begin{array}{l}\text { Simulated Monetary } \\
\text { Eligibility }\end{array}$ & $\begin{array}{c}0.087 \\
(0.027)\end{array}$ & $\begin{array}{l}-0.119 \\
(0.104)\end{array}$ & $\begin{array}{c}0.034 \\
(0.048)\end{array}$ & $\begin{array}{c}0.108 \\
(0.171)\end{array}$ \\
\hline Number of Obs. & 204,502 & 19,280 & 204,502 & 19,280 \\
\hline
\end{tabular}


Figure 1: Retirement Hazard Rates, Ages 55-69

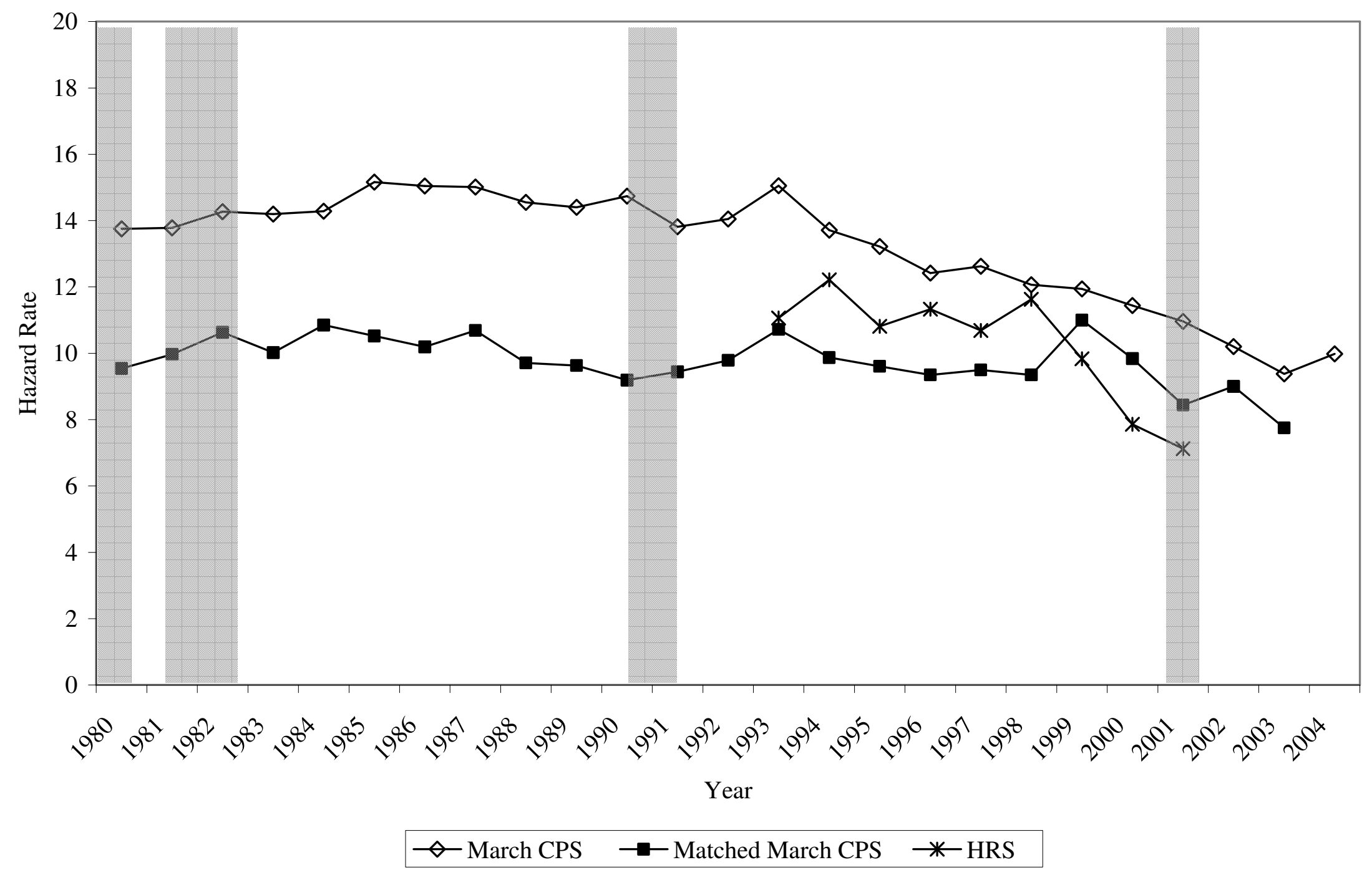

notes: shaded regions represent recessions, as defined by the National Bureau of Economic Research. Matched March CPS data for 1984 and 1994 does not exist; values are interpolated from surrounding years. 
Figure 2: Paths to Retirement in March CPS, Ages 55-69

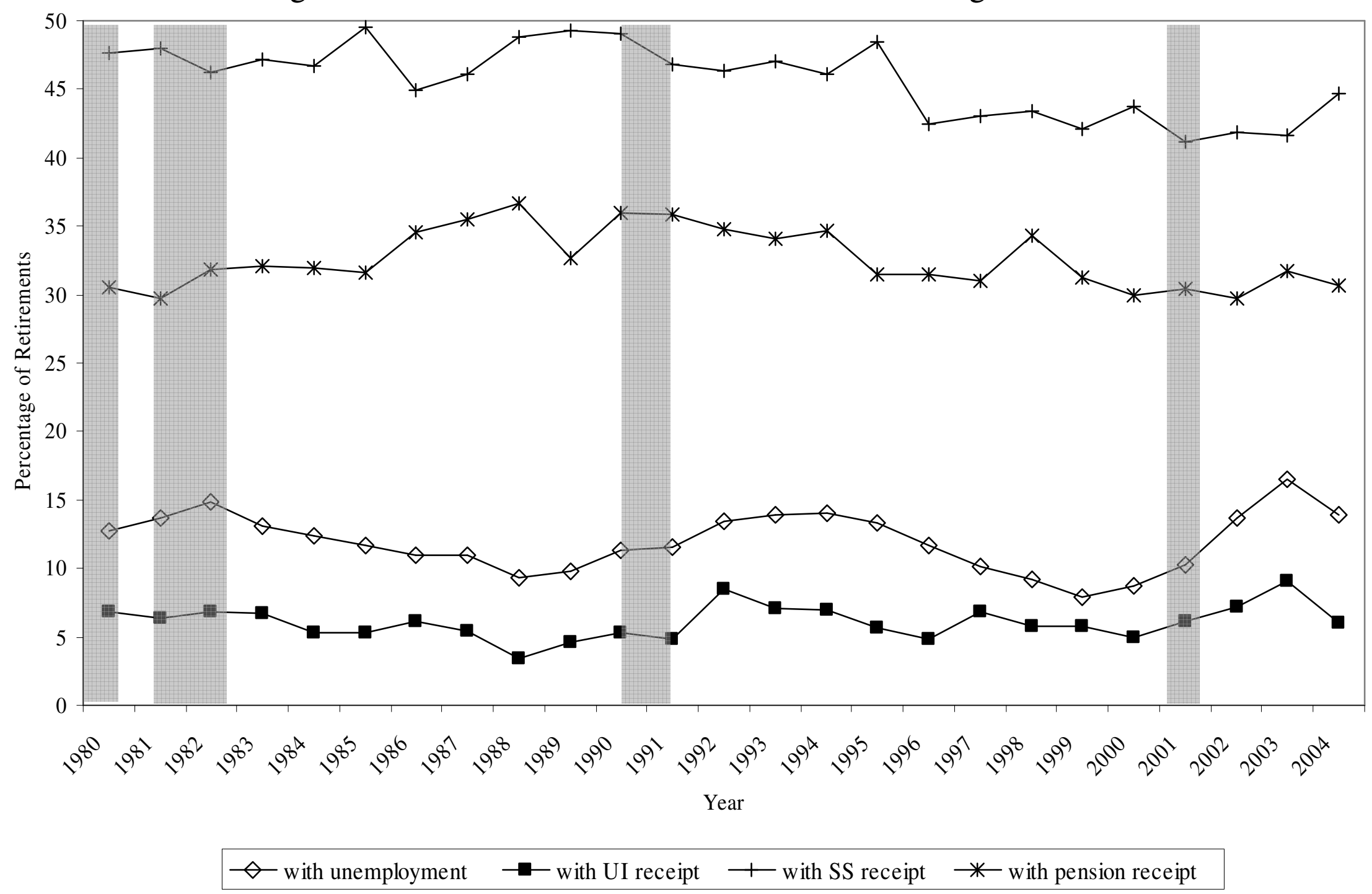

notes: shaded regions represent recessions, as defined by the National Bureau of Economic Research. 